\title{
KAJIAN DOSIS VESICULAR ARBUSCULAR MICORRHIZA (VAM) DAN PRODUK OLAHAN SEKAM TERHADAP PERTUMBUHAN DAN PRODUKSI TANAMAN KACANG HIJAU (Phaseolus radiatus L.)
}

\author{
Mariyatul Qibtiyah \\ Fakultas Pertanian, Universitas Islam Darul Ulum Lamongan,Jawa Timur- \\ Indonesia
}

\begin{abstract}
Abstrak.
Penelitian bertujuan mengetahui bagaimana pengaruh dosis vesicular arbuscular micorrhiza dan macam produk olahan sekam terhadap peningkatan pertumbuhan dan produksi kacang hijau. Penelitian menggunakan Rancangan Acak Kelompok yang diulang 3 kali. Perlakuan 1 : Mikoriza (M) terdiri dari 3 level yaitu: tanpa mikoriza (M0), mikoriza $100 \mathrm{~kg} / \mathrm{ha}$ (M1), mikoriza $150 \mathrm{~kg} / \mathrm{ha}$ (M2). Perlakuan 2 : Olahan Sekam terdiri dari 3 level yaitu: tanpa olahan sekam (SO), bokashi sekam 10 ton/ha (S1), dan sekam bakar 10 ton/ha (S2). Hasil penelitian menunjukkan adanya interaksi yang nyata antara perlakuan dosis vesicular arbuscular micorrhiza dan macam produk olahan sekam hanya pada parameter pengamatan tinggi tanaman umur 42 hst. Pada Perlakuan dosis vesicular arbuscular micorrhiza nilai terbaik yaitu pada penggunaan dosis $150 \mathrm{~kg} / \mathrm{ha}$ dan pada perlakuan macam olahan sekam, nilai terbaik adalah pada penggunaan bokhasi sekam.
\end{abstract}

Keywords : kacang hijau, vesicular arbuscular micorrhiza, olahan sekam

\section{PENDAHULUAN}

Kacang hijau (Phaseolus radiatus L.) merupakan salah satu jenis kacang-kacangan yang banyak diusahakan di Indonesia, seperti halnya kacang tanah dan kedelai, akan tetapi pembudidayaan masih terbatas, terutama pada daerah tertentu seperti Madura, Ponorogo dan Bojonegoro. Sebaliknya pembudidayaan kacang hijau lebih mudah dibandingkan dengan kacang-kacangan lainnya, karena mempunyai daya adaptasi yang tinggi, umur yang relatif pendek, dan cocok ditanam di lahan yang kurang air, di Indonesia kacang hijau menduduki urutan ketiga dari jenis tanaman kacang-kacangan, setelah kacang tanah dan kedelai (Andrianto dan Indarto, 2004).

Alamat Responden:

\section{Mariyatul Qibtiyah}

Fakultas Pertanian, Universitas Islam Darul Ulum Lamongan,Jawa TimurIndonesia

Mariyatulqibtiyah78@yahoo.co.id

Penggunaan pupuk anorganik secara terus menerus dan tidak diimbangi dengan penggunaan pupuk organik menyebabkan tanah menjadi keras sehingga produktivitasnya menurun (Dinata, 2012). Petani di Indonesia jarang menggunakan pupuk organik karena produktivitasnya 
rendah. Sejak tahun 1984, untuk meningkatkan hasil pertanian secara cepat, petani menggunakan pupuk anorganik (Supadma, 2006).

Menurut Talanca dan Adnan (2005) terbentuknya isoflavonoid yang mampu meningkatkan ketahanan tanaman terhadap pathogen tanah dapat dibentuk melalui infeksi mikroriza pada akar tanaman. Senyawa isoflavonoid sebagai senyawa metabolit sekunder yang banyak disintesa oleh tanaman. Pembentukan endomikoriza pada akar kedelai, dapat mendukung ketahanan tanaman dari serangan nematoda dan cendawan pathogen. Assosiasi mikoriza dapat menekan pertumbuhan dan perkembangan cendawan pathogen dan nematoda.

$$
\text { Fungi mikoriza sebagai }
$$
mikroorganisme tanah memiliki peranan penting antara lain memfasilitasi penyerapan unsur hara oleh tanaman, meningkatkan pertumbuhan tanaman pada lahan terdegradasi dan lahan tingkat kesuburan tanahnya rendah, serta memperluas fungsi sistem perakaran dalam memperoleh nutrisi ((Suharno dan Sufati, 2009; Garg dan Chandel, 2010).

Arang sekam sudah digunakan sebagai media tanam pengganti tanah dalam budidaya tanaman hias dan sayuran (terutama budidaya hidroponik). Peranan penting yang dimiliki arang sekam adalah memiliki sifat berongga (porous), ringan, bersih dan dapat menahan air. Arang sekam dapat diproduksi sendiri maupun diperoleh dengan mudah di took-toko pertanian (Maspary, 2011).

Bokhasi sekam merupakan pupuk organik yang dihasilkan dari proses fermentasi bahan organik dengan menggunakan inokulum EM 4. Bokashi sekam dapat menambah kesuburan tanah, meningkatkan pertumbuhan dan produksi tanaman kacang hijau (Simarmata dan Hamdani, 2003).

Peningkatan kesuburan tanah oleh bokashi dilakukan secara fisik yaitu dengan memperbaiki struktur tanah, yaitu dengan pembentukan agregat tanah. Perbaikan secara kimiawi terjadi dengan meningkatnya kandungan unsur hara tanah. Untuk perbaikan secara biologi, yaitu dengan meningkatnya populasi dan aktivitas mikroorganisme sehingga ketersediaan unsur hara juga meningkat (Sarief, 2004).

\section{METODE PENELITIAN}

Penelitian ini dilaksanakan di Desa Dukuh Agung, Kecamatan Tikung, Kabupaten Lamongan. Ketinggian tempat \pm 10 meter dpl. 
Waktu penelitian di laksanakan pada bulan Maret sampai Juni 2017. Bahan yang digunakan dalam penelitian ini adalah benih tanaman kacang hijau varietas Murai, Vesicular Arbuscular Micorrhiza (VAM), sekam, air, EM4, molase (Gula tetes), pupuk urea, $\mathrm{KCl}$, SP 36.

Alat-alat yang dgunakan yaitu pipa pembakaran, korek api, sekop, handsprayer, karung, cangkul, tugal, meteran, timbangan, papan nama, terpal, ajir, dan alat tulis.

Bokashi sekam dibuat dengan komposisi sebagai berikut: $50 \mathrm{~kg}$ sekam, EM4, $250 \mathrm{ml}$ gula tetes dan air. Cara pembuatan : Mencampurkan molase, EM4 dan air diaduk dan dibiarkan selama satu malam, kemudian disirimkan ke sekam dan diaduk sampai rata, lalu ditutup dengan terpal, dibuka dan diaduk setiap 1 minggu sekali. Setelah 30 hari bokhasi sekam siap digunakan. Bakaran sekam dibuat dengan cara membakar sekam namun tidak sampai menjadi abu, bakaran sekam yang dihasilkan berwarna hitam

Pengamatan pertumbuhan fase vegetative dilakukan saat tanaman mulai umur 14 hari setelah tanam dan dilakukan dengan interval 14 hari sekali. Selanjutnya dilakukan pengamatan panen. Data pengamatan yang diperoleh dianalisis dengan analisis ragam yaitu Uji $\mathrm{F}$ pada taraf 5\% untuk mengetahui ada tidaknya pengaruh perlakuan. Jika didapatkan hasil yang berbeda nyata maka dilakukan uji lanjut BNT dengan taraf 5\% untuk mengetahui perbedaan antar perlakuan.

\section{HASIL DAN PEMBAHASAN}

\subsection{Tinggi tanaman}

Hasil analisa sidik ragam didapat hasil berbeda nyata pada perlakuan dosis vesicular arbuscular mikoriza (VAM) terhadap pertumbuhan tinggi tanaman pada setiap pengamatan umur 14 hst dan berbeda sangat nyata pada umur 28 hst. Hal ini dapat dilihat pada tabel 1.

Pada pengamatan tinggi tanaman umur 42 hst didapatkan adanya interaksi antara perlakuan dosis VAM dan macam produk olahan sekam. Hal ini dapat dilihat pada tabel 2. 
Tabel 1. Hasil Perlakuan Dosis VAM terhadap Tinggi Tanaman $(\mathrm{cm})$ pada Umur 14 hst dan 28 hst.

\begin{tabular}{ccc}
\hline \multirow{2}{*}{ Perlakuan } & \multicolumn{2}{c}{ Rata-rata tinggi tanaman $(\mathrm{cm})$ umur ke } \\
\cline { 2 - 3 } & $14 \mathrm{hst}$ & $28 \mathrm{hst}$ \\
\hline Tanpa VAM & $47,87 \mathrm{a}$ & $109,45 \mathrm{a}$ \\
VAM dosis 100 kg/ha & $48,19 \mathrm{a}$ & $113,85 \mathrm{~b}$ \\
VAM dosis 150 kg/ha & $53,05 \mathrm{~b}$ & $127,55 \mathrm{c}$ \\
BNT 5\% & 1,43 & 3,32 \\
\hline
\end{tabular}

Keterangan : Pengaruh tidak berbeda nyata dengan uji BNT 5\% apabila diikuti oleh huruf yang sama dalam kolom yang sama.

HST : Hari setelah tanam.

Tabel 2. Hasil Perlakuan Dosis VAM terhadap Tinggi Tanaman (cm) pada 42 Hst.

\begin{tabular}{cc}
\hline Perlakuan & Rata-rata tinggi tanaman $(\mathrm{cm})$ umur \\
& $42 \mathrm{hst}$ \\
\hline Tanpa VAM tanpa olahan sekam & $59,63 \mathrm{a}$ \\
Tanpa VAM dan bokhasi sekam & $60,84 \mathrm{~b}$ \\
Tanpa VAM dan bakaran sekam & $62,82 \mathrm{c}$ \\
VAM 100 kg/ha tanpa olahan sekam & $63,07 \mathrm{c}$ \\
VAM 100 kg/ha dan bokhasi sekam & $63,54 \mathrm{c}$ \\
VAM 100 kg/ha dan bakaran sekam & $64,13 \mathrm{~d}$ \\
VAM 150 kg/ha tanpa olahan sekam & $64,36 \mathrm{~d}$ \\
VAM 150 kg/ha dan bokhasi sekam & $69,85 \mathrm{e}$ \\
VAM 150 kg/ha dan bakaran sekam & $69,83 \mathrm{e}$ \\
BNT 5\% & 1,04 \\
\hline
\end{tabular}

Keterangan : Pengaruh tidak berbeda nyata dengan uji BNT 5\% apabila diikuti oleh huruf yang sama dalam kolom yang sama.

\subsection{Berat Kering Total Tanaman}

Hasil analisa sidik ragam pada

Tabel 3. menunjukkan bahwa perlakuan dosis mikoriza dan perlakuan olahan sekam berbeda sangat nyata terhadap berat kering tanaman pada saat panen namun tidak terjadi interaksi antara kedua perlakuan.

\subsection{Berat Biji Pertanaman}

Hasil analisa sidik ragam pada Tabel 4. menunjukkan bahwa perlakuan dosis mikoriza dan pada perlakuan olahan sekam berbeda sangat nyata pada terhadap berat biji pertanaman pada saat panen namun tidak terjadi interaksi antara kedua perlakuan.

Tabel 3. Hasil Perlakuan Dosis mikoriza dan Perlakuan Olahan Sekam terhadap berat kering tanaman pada saat panen $(\mathrm{g})$ 


\begin{tabular}{cc}
\hline Perlakuan & Rata-rata Berat Kering Tanaman $(\mathrm{gr})$ \\
\hline Tanpa VAM & $402.00 \mathrm{a}$ \\
VAM dosis 100 kg/ha & $453.33 \mathrm{~b}$ \\
VAM dosis 150 kg/ha & $526.67 \mathrm{c}$ \\
BNT 5 \% & 12.86 \\
Tanpa olahan sekam & $424.67 \mathrm{a}$ \\
Bokhasi sekam & $482.67 \mathrm{c}$ \\
Bakaran sekam & $474.67 \mathrm{~b}$ \\
BNT 5\% & 12.86 \\
\hline
\end{tabular}

Keterangan: Angka-angka yang diikuti oleh huruf yang sama dalam kolom yang sama tidak berbeda nyata dengan uji BNT 5\%.

Tabel 4. Hasil Perlakuan Dosis Mikoriza dan Perlakuan Olahan Sekam Berat Biji Pertanaman (g).

\begin{tabular}{cc}
\hline Perlakuan & Rata-rata Berat Biji Pertanaman (gr) \\
\hline Tanpa VAM & $162.13 \mathrm{a}$ \\
VAM dosis 100 kg/ha & $168.40 \mathrm{~b}$ \\
VAM dosis $150 \mathrm{~kg} / \mathrm{ha}$ & $176.13 \mathrm{c}$ \\
BNT 5\% & 1,70 \\
Tanpa olahan sekam & $165.07 \mathrm{a}$ \\
Bokhasi sekam & $170.93 \mathrm{~b}$ \\
Bakaran sekam & $167.05 \mathrm{~b}$ \\
BNT 5\% & 1.70 \\
\hline
\end{tabular}

Keterangan: Pengaruh tidak berbeda nyata dengan uji BNT 5\% apabila diikuti oleh huruf yang sama dalam kolom yang sama.

Tabel 5. Hasil Perlakuan Dosis Mikoriza dan Perlakuan Olahan Sekam terhadap 1000 biji kering per petak percobaan (g).

\begin{tabular}{cc}
\hline Perlakuan & $\begin{array}{c}\text { Rata-rata Berat 1000 biji kering per petak } \\
\text { percobaan }(\mathrm{gr})\end{array}$ \\
\hline Tanpa VAM & $193.7 \mathrm{o} \mathrm{a}$ \\
VAM dosis 100 kg/ha & $199.60 \mathrm{~b}$ \\
VAM dosis 150 kg/ha & $207.33 \mathrm{c}$ \\
BNT 5 \% & 1.65 \\
Tanpa olahan sekam & $196.53 \mathrm{a}$ \\
Bokhasi sekam & $202.67 \mathrm{~b}$ \\
Bakaran sekam & $200.93 \mathrm{a}$ \\
BNT 5 \% & 1.65 \\
\hline Keterangan: Pengaruh tidak berbeda nyata dengan uji BNT 5\% apabila diikuti oleh \\
huruf yang sama dalam kolom yang sama.
\end{tabular}

\subsection{Berat 1000 biji kering per petak} percobaan

Hasil analisa sidik ragam menunjukkan bahwa terdapat hasil berbeda sangat nyata pada perlakuan dosis mikoriza dan pada perlakuan olahan sekam terhadap berat 1000 biji kering per petak percobaan pada saat panen namun tidak terjadi interaksi 
antara kedua perlakuan.Hal ini dapat dilihat pada tabel 5 .

Berdasarkan hasil analisa sidik ragam dari berbagai parameter pengamatan didapatkan hasil bahwa tidak terdapat interaksi antara perlakuan dosis VAM dan macam produk olahan sekam. Namun hasil analisa sidik ragam menunjukkan pada perlakuan dosis VAM, dosis yang paling baik dibandingkan dengan perlakuan lainnya yaitu $150 \mathrm{~kg} / \mathrm{ha}$ dan perlakuan produk olahan sekam yang paling baik dibandingkan dengan perlakuan lainnya yaitu bokhasi sekam untuk peningkatan pertumbuhan dan produksi tanaman kacang hijau.

Vesicular Arbuscular Micorrhiza (VAM) atau Cendawan Mikoriza Arbuskula (atau cendawan akar) diterapkan pertama kali oleh A.B Frank pada tahun 1885 pada asosiasi cendawan pohon (Handayanto dan Hairiah, 2007). Menurut Handayanto dan Hairiah, 2007, cendawan ini membentuk arbuskular (struktur bercabang banyak dalam sel kortek akar) yang menghasilkan Mikoriza Arbuskular. Cendawan ini dapat meningkatkan serapan fosfor oleh tanaman melalui hifa ekstramatrik (hifa diluar akar) yang dihasilkan (Handayanto dan Hairiah, 2007).

Mikoriza merupakan bentuk simbiosis menguntungkan antara fungi dan sistem perakaran pada tumbuhan. Peran mikoriza antara lain membantu penyerapan unsur hara dan pasokan air pada tanaman, meningkatkan pertumbuhan serta hasil produksi tanaman.

Simbiosis mikoriza dengan tumbuhan tidak banyak berpengaruh positif pada lahan subur, tetapi pada kondisi lahan yang ekstrim dan kurang subur dapat meningkatkan pertumbuhan tanaman (Smith dan Read, 2008).

Fungi mikoriza sebagai mikroorganisme tanah memiliki peranan penting antara lain memfasilitasi penyerapan unsur hara oleh tanaman, meningkatkan pertumbuhan tanaman pada lahan terdegradasi dan lahan tingkat kesuburan tanahnya rendah, serta memperluas fungsi sistem perakaran dalam memperoleh nutrisi ((Suharno dan Sufati, 2009; Garg dan Chandel, 2010).

Mikoriza dapat meningkatkan daerah penyerapan akar akibat terjadinya perluasan permukaan kontak dengan tanah. Hal ini mempermudah akses unsur hara, utamanya phospat (P) di dalam tanah. Mikoriza juga mampu meningkatkan ketahanan terhadap cekaman biotic dan abiotik (Smith dan Read, 2008). 
Marin (2006), mengemukakan bahwa lebih dari $80 \%$ pada ekosistem alam dan pertanian, tanaman mampu memiliki simbiosis dengan mikoriza. Simbiosis ini berperan penting dalam pertumbuhan, kesehatan dan produktivitas tanaman. Cendawan mikoriza dapat menginfeksi semua tanaman, umumnya tanaman yang memiliki mikoriza berasal dari familia Gamineae dan Leguminosa. Kedelai, kacang tunggak, gandum, nanas, bawang, pepaya, padi gogo, singkong, daun selada dan sorghum adalah tanaman yang dilaporkan pernah terinfeksi mikoriza vesicular arbuskular

Penggunaan bokhasi sekam dapat disebut sebagai pertanian yang ramah lingkungan, hal ini disebabkan bhokasi sekam dapat memperbaiki fungsi tekstur dan juga hidrologi tanah,sehingga aliran air dalam tanah akan menjadi baik.

Menurut Pangaribuan et al. (2011), Bokashi sekam padi berpotensi sebagai bahan organik, yang merupakan produk hasil olahan fermentasi sekam padi dengan EM-4. Pemberian bokashi sekam padi dan pupuk phospat (P) ditujukan untuk meningkatkan produksi padi melalui peningkatan ketersediaan phospat, meningkatkan kesuburan fisik, kimia, dan biologi tanah. Hasil analisa hasil pengomposan jerami padi memiliki komposisi : $1.83 \%(\mathrm{~N}), 0.12 \%(\mathrm{P})$, $1.59 \%(\mathrm{~K}), 34.03 \%$ (C Organik).

Kandungan unsur hara dan bahan organik yang dimiliki Bokashi dari sekam padi mampu memperbaiki tanah secara fisik, kimia, dan biologi. Bahan organik berfungsi untuk membantu penyerapan unsur hara dalam tanah dan berperan dalam pertukaran kation dan anion sehingga pertumbuhannya juga baik. Menurut Murbando (2005), bahan organik mampu meningkatkan ketersediaan unsur hara dalam pertumbuhan tanaman. Hal ini terjadi karena bahan organik berperan dalam proses mineralisasi yang dapat menciptakan kondisi pertumbuhan tanaman yang lebih baik. Selain itu, bahan organik dapat memperbaiki pertumbuhan dan produksi tanaman melalui perbaikan tanah secara fisik, kimia dan biologi.

$$
\text { Menurut Roro }
$$

Kesumaningwati (2014), pemanfaatan sisa panen berupa bokashi sekam pada tanah sawah mampu meningkatkan $\mathrm{pH}$ tanah walaupun tidak besar peningkatannnya. Aroning (2005), menyatakan bahwa bahan organik dalam tanah memiliki peranan antara lain, menambah unsur hara dalam tanah, memperbaiki struktur tanah, menjadikan akar lebih berkembang (membuat aerasi tanah lebih baik dan 


\begin{abstract}
memperbaikin densitas tanah) sehingga unsur hara mudah terserap lebih banyak. Hal ini berpengaruh pada volume akar dan sistem perakaran yang lebih baik,sehingga pertumbuhan dan perkembangan tanaman juga akan lebih baik.
\end{abstract}

\title{
IV. KESIMPULAN
}

1. Terdapat interaksi antara perlakuan dosis VAM dan macam produk olahan sekam pada parameter tinggi tanaman umur 42 hst.

2. Perlakuan dosis $150 \mathrm{~kg} / \mathrm{ha}$ VAM dan bokhasi sekam merupakan perlakuan yang memiliki nilai tertinggi yang dapat meningkatkan pertumbuhan dan produksi tanaman kacang hijau lebih baik dibandingkan dengan perlakuan lainnya.. 


\section{DAFTAR PUSTAKA}

Andrianto, T. T. dan Indarto, N. 2004. Budidaya dan Analisis Tani Kedelai, Kacang Hijau, Kacang Panjang. Absolut. Yogyakarta. Hal: 93

Aroning, 2005. Aplikasi Berbagai Pupuk Organik Pada Tanaman Kacang Hijau di Lahan Kering. Jurnal Sains \& Teknologi, Agustus 2005. Vol. 5 No. 2: 65

Dinata, A. 2012. Hubungan Pupuk Kandang dan NPK Terhadap Bakteri Azotobacter dan Azospirillum dalam Tanah Serta Peran Gulma Untuk Membantu Kesuburan Tanah. http://marco 58dinata.blogspot. com /2012/10/hubunganpupuk-kandang-dan-npkterhadap.html.

Tanggal akses 17 Juni 2016.

Handayani, T.A. 2012. Produksi Kedelai Organik Berdasarkan Perbedaan Dosis Pupuk Dan Fungi Mikoriza Arbuskula. Skripsi. Departemen Agronomi Dan Hortikultura Fakultas Pertanian Institut Pertanian Bogor. Bogor.

Pangaribuan, Darwin dan Pujisiswanto, Hidayat. 2011. Pemanfaatan Kompos Jerami
Untuk Meningkatkan Produksi dan Kualitas Buah Tomat. Prosiding Seminar Nasional Sains dan Teknologi-II 2008 Universitas Lampung

Simarmata, T. dan J. S. Hamdani., 2003. Efek kombinasi jenis pupuk organik dengan bionutrisi terhadap pertumbuhan dan hasil tanaman jahe (Zingiber officinale Rosc.) pada inceptisol digarut. J. Bionat. 5 (1) : 29-37.

Supadma, A. A. N. 2006. Uji Kombinasi Pupuk Organik dan Anorganik terhadap Hasil Jagung Manis serta Kepadatan Tanah Inceptisol Tabanan. Agritrop, 25(2):51-56.

Roro Kesumaningwati. 2014. Pemanfaatan sisa panen dalam bentuk bokashi sekam Terhadap peningkatan beberapa sifat kimia (ph, c organik, n, p, dan k) tanah sawah.Fakultas Pertanian Universitas Mulawarman, Samarinda, Kalimantan Timur.

Talanca, H. Dan Adnan, A.M. 2005. Mikoriza dan Manfaatnya pada Tanaman. Prosiding Seminar Ilmiah dan Pertemuan Tahunan PEI dan PFI XVI Komda. 